\title{
Phosphomannose-isomerase as a selectable marker to recover transgenic orchid plants (Oncidium Gower Ramsey)
}

\author{
Muthu Thiruvengadam • Wei-Han Hsu • \\ Chang-Hsien Yang
}

Received: 18 January 2010/ Accepted: 16 August 2010/Published online: 5 September 2010

(C) The Author(s) 2010. This article is published with open access at Springerlink.com

\begin{abstract}
A transformation method using the phosphomannose-isomerase (pmi) gene as a selectable marker was developed for orchid Oncidium Gower Ramsey. The pmigene, which converts mannose-6-phosphate to fructose-6phosphate allowing for selection of transgenic plants on mannose selective medium. Genetically transformed plants of Oncidium were regenerated after cocultivating protocorm-like bodies with Agrobacterium tumefaciens strain GV3101 containing the vectors pEPYON-42P and pEPYON-42H with 35S::PMI and 35S::HPTII genes respectively. We observed that $35 \mathrm{~S}:: P M I$ (pEPYON-42P) produced high rate (27 plants) of mannose resistant transgenic plants compared to $35 \mathrm{~S}:: H P T I I$ (pEPYON-42H) in which only fourteen hygromycin resistant transgenic plants were obtained. Mannose resistant transgenic plants were confirmed by PCR and Southern blot. The pmi gene expression in 35S::PMI (pEPYON-42P) transgenic plants was confirmed by RT-PCR. Furthermore, the duration of regeneration time of transgenic plants was significantly shorter in mannose selected system (4 months) than in hygromycin selected system ( 8 months). The pmi/mannose selection system is shown to be highly efficient for producing transgenic $O$. Gower Ramsey without using antibiotics or herbicides. For the first time, the pmil mannose-based "positive" selection system has been used to obtain genetically engineered $O$. Gower Ramsey.
\end{abstract}

Keywords Agrobacaterium tumefaciens · Mannose . Oncidium · Positive selection · Protocorm-like bodies

M. Thiruvengadam $(\bowtie) \cdot$ W.-H. Hsu · C.-H. Yang

Graduate Institute of Biotechnology, National Chung Hsing

University, Taichung 40227, Taiwan, ROC

e-mail: thiruv30@yahoo.com

\author{
Abbreviations \\ AS Acetosyringone \\ PLB Protocorm-like body \\ MS Murashige and Skoog \\ Man Mannose \\ PMI Phosphomannose-isomerase \\ Suc Sucrose
}

\section{Introduction}

Orchids are one of the most important ornamental plants that occupy top position among all flowering plants which has been valued for cut flower production and potted plants. The genus Oncidium (Orchidaceae) comprises a number of commercially important species that have produced a wide range of attractive varieties, cultivars or hybrids as a result of intensive breeding. Oncidium Gower Ramsey is a major and popular ornamental plant for the worldwide market and high value cash crop plant. The demand of this plant for cut flowers and potted plants has been increasing worldwide. Its many characteristics have been improved through conventional breeding programs. Compared with conventional breeding, the molecular transformation technique is an alternative approach to introduce specific characteristics into plants and is advantageous for crop improvement, especially for the modification of ornamental characteristics such as flowering time, shelf life, flower colour and architecture. The currently available methods for selecting transgenic Oncidium are based on antibiotic selection using hygromycin (Liau et al. 2003; Li et al. 2005) and kanamycin (Thiruvengadam and Yang 2010). However, the presence of antibiotic marker genes, seen as an unpredictable hazard to the ecosystem and human health, can be solved by removing 
the selectable antibiotic marker gene. The avoidance of antibiotic or herbicide resistance markers in genetic engineering plants has been encouraged. Several positive selection systems have been developed in recent years. These include systems based on nonmetabolizable agents such as xylulose (Haldrup et al. 1998), mannose (Joersbo et al. 1998; Negrotto et al. 2000; Reed et al. 2001), 2deoxyglucose (Kunze et al. 2001), benzyladenine-N-3-glucuronide (Joersbo and Okkels 1996) or based on the promotion of plant regeneration without the use of a selective agent, such as isopentenyl transferase (Endo et al. 2001; Zuo et al. 2002). In previous reports of Oncidium transgenic plant selection utilizing the sweet pepper ferredoxin-like protein ( $p f p$ ) gene and Erwinia carotovora as the selection agent (You et al. 2003).

The PMI enzyme is common in nature and found across kingdoms, but is less common in the plant kingdom (Goldsworthy and Street 1965). The enzyme is present in soybeans and other legumes, but absent in many other plants (Lee and Matheson 1984). The manA gene codes for the enzyme PMI (E.C. 5.3.1.8) isolated from Escherichia coli (Miles and Guest 1984). In the presence of mannose in transformed cells, the PMI converts mannose-6-phosphate into fructose-6-phosphate that can be immediately incorporated in the plant metabolic pathway (Privalle et al. 1999). Thus, the mannose can be used as sole source of carbohydrate for the transformed cells. Mannose cannot be usually metabolized by non-transformed cells and is converted into mannose-6-phosphate by endogenous hexokinase. Therefore, when mannose is added to the culture medium, it could minimize the plant growth due to mannose-6-phosphate accumulation. This PMI selection system is extremely efficient (Joersbo et al. 1998). In addition, the selection gene product is harmless; because of the safety assessment for PMI has revealed that purified PMI protein has no unfavorable effects in a mouse toxicity test and does not change glycoprotein profiles in PMI transformed plants (Reed et al. 2001).

The pmi/Man system has been successfully used in several plant systems such as sugar beet (Joersbo et al. 1998), cassava (Zhang and Puonti-Kaerlas 2000), maize (Negrotto et al. 2000; Wright et al. 2001), Arabidopsis (Todd and Tague 2001), wheat (Wright et al. 2001), tobacco and potato
(Kunze et al. 2001), pepper (Kim et al. 2002), sweet orange (Boscariol et al. 2003), pearl millet (O'Kennedy et al. 2004), tomato (Sigareva et al. 2004), papaya (Zhu et al. 2005), bentgrass (Fu et al. 2005), apple (Degenhardt et al. 2006), onion (Aswath et al. 2006), almond (Ramesh et al. 2006), cucumber (He et al. 2006), cabbage (Min et al. 2007), sugarcane (Jain et al. 2007), flax (Lamblin et al. 2007), citrus (Ballester et al. 2008), sorghum (Gurel et al. 2009) and chickpea (Patil et al. 2009). However, the pmi/Man system has not been tested previously in Oncidium orchid. In the present study, we report the development of an efficient system with mannose as a selectable agent for the Agrobacterium-mediated transformation of Oncidium orchid.

\section{Materials and methods}

Bacterial strains and plasmids

Genomic DNA from Escherichia coli strains TOP10 was extracted by TRIzol reagent (Invitrogen). The PMI coding sequence was amplified by PCR using the forward primer EcPMI-For 5'-GCTCGAGCATGCAAAAACTCATTAACT CAG- $3^{\prime}$ and reverse primer EcPMI-Rev 5'-GCTCGAG TTACAGCTTGTTGTAAAC- $3^{\prime}$. The specific forward and reverse primers for PMI contained the generated XhoI recognition site (5'-CTCGAG- $3^{\prime}$, underlined) to facilitate the cloning of the DNA. The plant transformation vector pEpyon- $42 \mathrm{H}$ has the hygromycin phosphotransferase (hptII) gene driven by duplicated $(2 \times)$ CaMV35S promoter and contains GFP marker gene fused with promoter and first intron of monocot maize ubiquitin 1 (Ubi-1) gene (data not shown). The vector pEpyon42P was constructed by removing hygromycin phosphotransferase (hptII) gene from pEpyon-42H by XhoI digestion and replaced with the pmi gene (Fig. 1, CHY Lab, Taichung, Taiwan, unpublished). The plasmid pEpyon was introduced into Agrobacterium tumefaciens strains GV3101 by Freeze Thaw method (Höfgen and Willmitzer 1988). A single colony of Agrobacterium was incubated overnight in $5 \mathrm{ml}$ liquid LB medium with $100 \mathrm{mg} \mathrm{l}^{-1}$ kanamycin and $15 \mu \mathrm{g} / \mathrm{ml}$ gentamycin on a shaker $(180 \mathrm{rpm})$ at $28^{\circ} \mathrm{C}$. An aliquot of the bacterial suspension $(25 \mathrm{ml})$ was transferred to $50 \mathrm{ml}$ fresh medium and cultured for $12-18 \mathrm{~h}$ to an OD600 0.7-1.0.

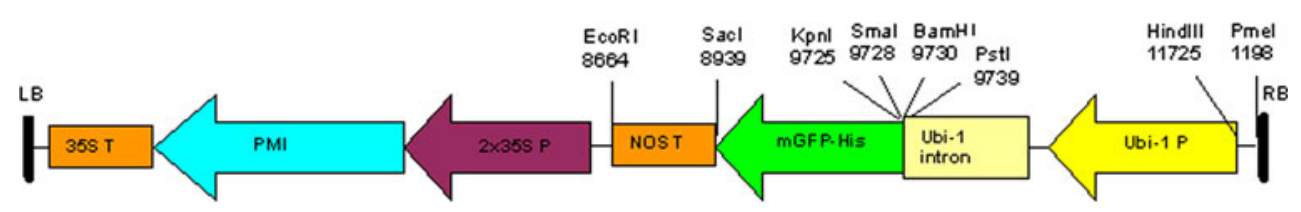

Fig. 1 a schematic representation of the plant transformation vector pEpyon-42P (12,057 bp). The pEpyon-42P contained the phosphomannose-isomerase (pmi) gene driven by duplicated $(2 \times)$ CaMV35S promoter and a GFP marker gene fused with promoter and first intron of monocot Maize Ubiquitin 1 (Ubi-1) gene 
Bacterial cells were harvested by centrifugation at 3,000 rpm for $10 \mathrm{~min}$ in a $50-\mathrm{ml}$ sterile centrifuge tube (Corning, NY, USA) and then resuspended in $30 \mathrm{ml}$ of in liquid MS medium supplemented with $100 \mu \mathrm{M}$ acetosyringone (Sigma, Saint Louis, MO, USA).

Plant material and culture conditions

PLBs of the commercial variety of Oncidium Gower Ramsey were used as explants. They were maintained by subculturing chopped PLBs onto G10 (Liau et al. 2003) medium modified with MS salts, $20 \mathrm{~g} \mathrm{l}^{-1}$ sucrose, $3.0 \mathrm{~g}^{-1}$ phytagel, $1.0 \mathrm{~g} \mathrm{l}^{-1}$ tryptone (Sigma), $1.0 \mathrm{~g} \mathrm{l}^{-1}$ charcoal, $30 \mathrm{~g} \mathrm{l}^{-1}$ potato tubers and $30 \mathrm{~g} \mathrm{l}^{-1}$ banana at $\mathrm{pH}$ 5.6 and incubated with a $16-\mathrm{h}$ photoperiod at $25^{\circ} \mathrm{C}$. Light was provided by cool white fluorescent lamps with an intensity of $120 \mu \mathrm{mol} \mathrm{m}{ }^{-2} \mathrm{~s}^{-1}$. Newly formed PLBs of 45 day-old cultures were chopped and cultured in G10 medium, and then incubated at $25^{\circ} \mathrm{C}$ in the dark for 3 days.

Determination of mannose and hygromycin concentration for selection

To determine the optimum concentration of mannose and hygromycin inhibiting shoot formation of PLBs, explants were placed on regeneration medium containing various concentrations of mannose $\left(0-30 \mathrm{~g} \mathrm{l}^{-1}\right)$ in combination with different concentration of sucrose $\left(0-20 \mathrm{~g} \mathrm{l}^{-1}\right)$ (Fig. 2) and hygromycin (1.0-7.0 $\mathrm{mg} \mathrm{l}^{-1}$ ) (data not shown). After 5 weeks, explants were morphologically evaluated by determination of percentage of necrotic explants, and the number of produced new PLBs was recorded.

\section{Genetic transformation of Oncidium}

The 3-days precultured PLBs were transferred into Agrobacterium suspension with $100 \mu \mathrm{M}$ acetosyringone and

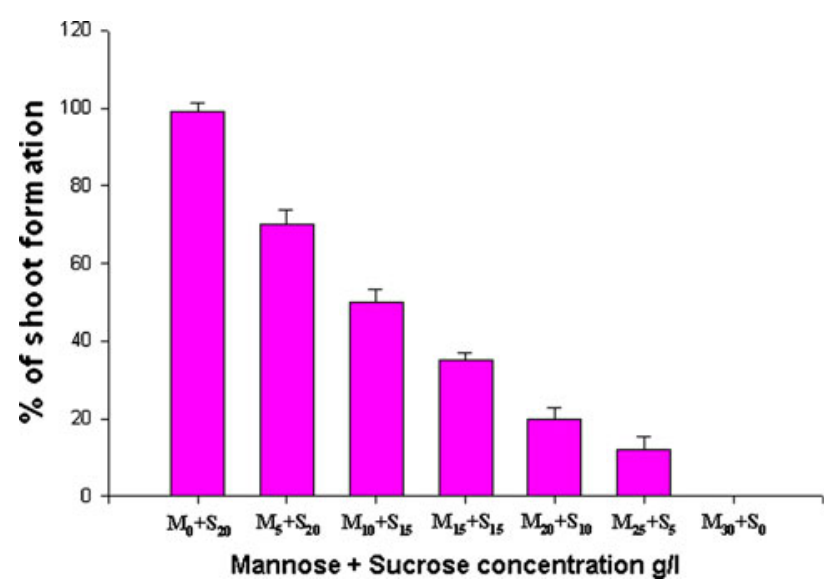

Fig. 2 Effect of various combinations of mannose and sucrose on regeneration of Oncidium Gower Ramsey. $M$ Mannose, $S$ Sucrose soaked for $30 \mathrm{~min}$, with occasional shaking, in a sterile flask, then blotted dry on sterile filter paper. The PLBs were plated on cocultivation medium, which was MS (Murashige and Skoog 1962) medium supplemented with $200 \mu \mathrm{M}$ acetosyringone, $30 \mathrm{~g} \mathrm{l}^{-1}$ sucrose, and $2.0 \mathrm{~g} \mathrm{l}^{-1}$ Gelrite at $\mathrm{pH} 5.8$ and cultured in the dark for 3 days. The infected PLBs were washed with MS medium containing $300 \mathrm{mg} \mathrm{l}^{-1}$ timentin to prevent Agrobacterium over growth and then transferred to the selection medium containing G10 supplemented with MS salts, $25 \mathrm{~g} \mathrm{l}^{-1}$ mannose (partially in place of sucrose, different concentrations of mannose and sucrose listed in Fig. 2 were used), $5.0 \mathrm{~g} \mathrm{l}^{-1}$ sucrose, $1.0 \mathrm{~g}^{-1}$ tryptone, $1.0 \mathrm{~g} \mathrm{l}^{-1}$ charcoal, $30 \mathrm{~g} \mathrm{l}^{-1}$ potato tubers, $30 \mathrm{~g} \mathrm{l}^{-1}$ banana, $300 \mathrm{mg} \mathrm{l}^{-1}$ timentin and $3.0 \mathrm{~g}^{-1}$ phytagel at $\mathrm{pH}$ 5.6, and cultured under a $16 / 8$-h (light/dark) photoperiod at $26 \pm 1{ }^{\circ} \mathrm{C}$ and subcultured every week for 1 month. Transformed PLBs were transferred to G10 medium supplemented with $25 \mathrm{~g} \mathrm{l}^{-1}$ mannose $5.0 \mathrm{~g} \mathrm{l}^{-1}$ sucrose and $300 \mathrm{mg} \mathrm{l}^{-1}$ timentin for selecting putative transgenic plantlets within 3 months. Regenerated plants about $3-4 \mathrm{~cm}$ in height with five to six leaves and three to four roots were eventually transferred to pots containing sphagnum moss and acclimatized under greenhouse conditions. The same transformation protocol followed in 35S::HPTII (pEPYON-42H) and selection medium containing $5.0 \mathrm{mg} \mathrm{l}^{-1}$ hygromycin and $300 \mathrm{mg}^{-1}$ timentin was used.

\section{PCR assay}

Genomic DNA was isolated from the fresh leaves $(100 \mathrm{mg})$ of putative transgenic and non transgenic plants using DNeasy Plant Mini Kit (Qiagen, Valencia, CA). PCR analysis was carried out with the genomic DNA to identify the presence of transgene. Primers used for the PCR to detect pmi gene insertion were EcPMI-For and EcPMI-Rev. The total volume of reaction mixtures was $20 \mu \mathrm{l}$, including 20 ng genomic DNA, $0.5 \mu \mathrm{l}$ of each primer $(20 \mu \mathrm{M}), 1.5 \mu \mathrm{l}$ of dNTP mix $(2.5 \mathrm{mM}), 2.0 \mu \mathrm{l}$ buffer $(10 \times)$ with $\mathrm{MgCl}_{2}$ $(15 \mathrm{mM})$ and $0.5 \mu \mathrm{l}$ Taq DNA polymerase. Cycling parameters began with an initial hot start at $95^{\circ} \mathrm{C}$ for $5 \mathrm{~min}$, then 35 cycles of denaturation $\left(95^{\circ} \mathrm{C} ; 1 \mathrm{~min}\right)$, annealing $\left(55^{\circ} \mathrm{C} ; 1 \mathrm{~min}\right)$, and extension $\left(72^{\circ} \mathrm{C} ; 45 \mathrm{~s}\right)$, followed by a final extension of $20 \mathrm{~min}$ at $72^{\circ} \mathrm{C}$. The expected PCR products were $700 \mathrm{bp}$. PCR amplification products were analyzed by electrophoresis in $1 \%$ agarose gels.

\section{Southern hybridization}

Genomic DNA $(15 \mu \mathrm{g})$ isolated from fresh leaves of PCRpositive transgenic plants, as well as nontransgenic control plants, was treated with BamHI, which digested at a unique site within the plasmid DNA, and separated on $1 \%$ agarose gels. Following gel electrophoresis, DNA was transferred 
to Hybond $\mathrm{N}+$ (Amersham, Buckinghamshire, UK) nylon membrane as described by Sambrook et al. (1989). A PCRgenerated pmi gene fragment (700 bp) was used as a probe. The probe was radiolabelled with $\alpha \mathrm{P}^{32} \mathrm{dCTP}$ according to the manufacturer's instructions (DECAprime ${ }^{\mathrm{TM}} \mathrm{II}$, random primed DNA labeling kit, Ambion) and used for hybridization. Prehybridization, hybridization and washing were performed according to standard methods (Sambrook et al. 1989). The membranes were washed at $60^{\circ} \mathrm{C}$ twice with $2 \times$ SSC and $0.5 \%$ SDS (20 min each) and twice with $1 \times$ SSC and $0.1 \%$ SDS for $20 \mathrm{~min}$. The washed blots were exposed to X-ray film (Kodak X-omat) with intensifying screens for signal detection at $-80^{\circ} \mathrm{C}$.

\section{Total RNA isolation and RT-PCR}

Total RNA was isolated from leaves of PCR positive transgenic plants and non transformed plants using the Trizol method according to instructions of the manufacturer. For cDNA synthesis, total RNA $(1 \mu \mathrm{g})$ was reverse-transcribed in a $20 \mu \mathrm{l}$ reaction mixture using the $\mathrm{BcaBEST}^{\mathrm{TM}}$ RNA PCR system (TaKaRa Shuzo Co., Shiga, Japan). A $5.0 \mu$ of cDNA sample from RT reaction was used for PCR. Primers used for the RT-PCR to detect pmi gene expression were EcPMI-For and EcPMI-Rev. The fragment was amplified under the following conditions: one cycle of $95^{\circ} \mathrm{C}$ for $5 \mathrm{~min} ; 35$ cycle of $95^{\circ} \mathrm{C}$ for $1 \mathrm{~min}, 55^{\circ} \mathrm{C}$ for $1 \mathrm{~min}$, and $72^{\circ} \mathrm{C}$ for $45 \mathrm{~s}$; and finally elongated at $72^{\circ} \mathrm{C}$ for $20 \mathrm{~min}$. The expected PCR products were $700 \mathrm{bp}$. The RT-PCR products were separated on a $1 \%$ agarose gel by electrophoresis.

\section{Experimental design and data analysis}

All the experiments were conducted with a minimum of 3 replicates per treatment. The experiments were repeated three times. The data were analyzed statistically using SPSS ver 14 (SPSS Inc., Chicago, USA). The significance of differences among means was confirmed using Duncan's multiple range test at $P=0.5$. The results are expressed as a means \pm SE of three experiments.

\section{Results}

Selection of mannose-resistant PLBs

As the pEpyon-42P contains the pmi gene which confers mannose resistance, we used the mannose as selection agent in our transformation experiments. In order to determine the sensitivity of mannose, Oncidium PLBs were cultured in various concentrations and combinations of mannose and sucrose (Fig. 2). The shoot growth decreased when mannose concentration increased (Fig. 2). In addition, with mannose in the medium, the shoot did not grow if the sucrose is not present. Sucrose is clearly the energy source for shoot regeneration. On medium lacking mannose, $100 \%$ of control PLBs (untransformed explants) produced shoots (Fig. 2). The inhibitory effects of mannose were observed in 1 month culture of wild type PLBs (Fig. 3a). However, with mannose concentrations over $25 \mathrm{~g} \mathrm{l}^{-1}$ without sucrose, the new PLBs did not develop (Fig. 2). We had chosen as the most appropriate concentration of mannose $25 \mathrm{~g} \mathrm{l}^{-1}$ and sucrose $5 \mathrm{~g} \mathrm{l}^{-1}$ for the selection of transformants in subsequent experiments.

Agrobacterium-mediated transformation and selection of putative transgenic plants

The pEpyon-42P containing pmi gene was transformed into Oncidium orchid PLBs via A. tumefaciens-mediated transformation. After the proliferation stage, mannose was used to select the putative transformants. After subculture, the transformed PLBs were green and rapidly grew whereas the untransformed PLBs turned brown and starved in the G10 medium with $25 \mathrm{~g} \mathrm{l}^{-1}$ mannose and $5 \mathrm{~g} \mathrm{l}^{-1}$ sucrose (Fig. 3b). After the surviving PLBs were sub-cultured, shoots developed rapidly, and roots were formed
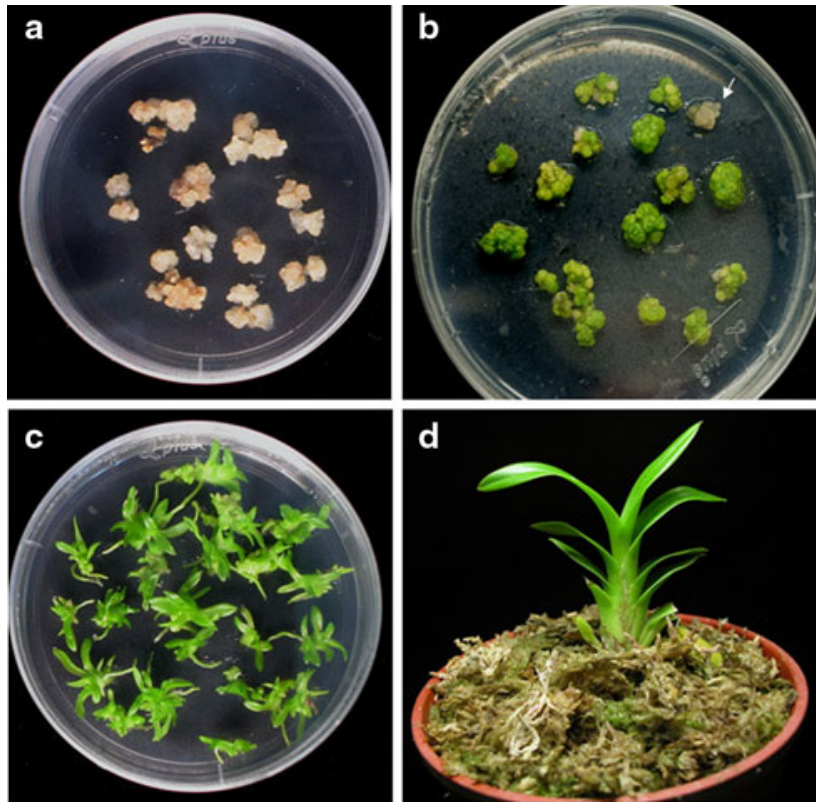

Fig. 3 Regeneration of PLB explants of Oncidium in mannose selection medium. a Non transgenic PLBs cultured on G10 medium with $25 \mathrm{~g} \mathrm{l}^{-1}$ mannose and $5 \mathrm{~g} \mathrm{l}^{-1}$ sucrose. b Transgenic PLBs (pEPYON-42P) cultured on selection medium $\left(\mathrm{G} 10+25 \mathrm{~g} \mathrm{l}^{-1}\right.$ mannose and $5 \mathrm{~g} \mathrm{l}^{-1}$ sucrose $+300 \mathrm{mg} \mathrm{l}^{-1}$ timentin). (Arrow indicated of untransformed PLBs). c Shoots and roots were well developed from pEPYON-42P transformants cultured on G10 medium containing $25 \mathrm{~g} \mathrm{l}^{-1}$ mannose with $5 \mathrm{~g}^{-1}$ sucrose and $300 \mathrm{mg}^{-1}$ timentin. d A transgenic plant of 35S::PMI (pEPYON42P) grown on sphagnum moss 
spontaneously after 1 month (Fig. 3c). From one hundred transformed PLBs used for transformation experiment, 69 PLBs survived mannose selection and 27 putative transgenic plants were regenerated from culture (Tables 1,2). All 27 putative transgenic plants were produced from PLBs within 4 months. These transgenic plants exhibited a normal phenotype (Fig. 3d). We randomly selected four independent mannose resistant putative transgenic orchid plants for molecular analyses.

Molecular analyses of transgenic plants

To confirm that these plants were transformants, total DNA and RNA were isolated and analyzed from the leaves of both non transformed plants and four pEpyon-42P transgenic plants. All tested transgenic lines showed the specific fragments of pmi gene (700 bp) detected by PCR, while no fragment was amplified in non transformed wild type plants (Fig. 4a). Foreign gene integration into the transgenic plant was confirmed by Southern blot analysis. Southern blot analysis was performed on genomic DNA from four independent PCR positive transgenic Oncidium plants (Fig. 4b, lanes 1-4). Results show that all four transgenic lines have a single copy of the transgene integrated into their genome, while no signal was detected in the untransformed control (Fig. 4b, lane 5). The presence of DNA for pmi gene in pEpyon-42P transgenic leaves testified truth of the transgenic plants. Furthermore, RT-PCR was performed and the results confirmed that $p m i$ was strongly expressed in four pEpyon-42P transgenic plants (Fig. 4c). According to the results of PCR, Southern blot and RT-PCR, we believed that the pmi was introduced into these transformed plants.

Comparison of transformation efficiencies in mannose and hygromycin resistant plants

Parallel experiments were performed to compare the transformation efficiencies and culture duration for regeneration in mannose (pEpyon-42P) and hygromycin ( $\mathrm{pEp}$ yon-42H) selection systems (Fig. 5a, b). A total 69/100 for pEpyon-42P and 42/100 for pEpyon-42H were survived in mannose and hygromycin selection respectively. Twentyseven putative pEpyon-42P mannose resistant plants and fourteen pEpyon-42H hygromycin resistant plants were successfully regenerated from culture (Table 2). PCR screening revealed that the pmi gene was detected in $21.0 \%$ of the plants regenerated after mannose selection (Table 1, Fig. 5a) and the hygromycin selection system was $9 \%$ (Fig. 5a). In addition, we compared the duration of

Table 1 Transformation efficiency of pEPYON-42P transformed Oncidium PLBs using various concentrations of mannose and sucrose

\begin{tabular}{llllll}
\hline Selection marker & & $\begin{array}{l}\text { No. of PLBs } \\
\text { explants infected }\end{array}$ & $\begin{array}{l}\text { No. of rooted } \\
\text { plantlets }\end{array}$ & $\begin{array}{l}\text { PCR positive } \\
\text { plants }\end{array}$ \\
\hline Mannose & Sucrose & 100 & $12 \mathrm{~cd}$ & $\begin{array}{l}\text { Transformation } \\
\text { frequency }(\%)\end{array}$ \\
\hline 0 & 20 & 100 & $10 \mathrm{c}$ & 0 & 0 \\
10 & 20 & 100 & $6 \mathrm{e}$ & 0 & 0 \\
15 & 15 & 100 & $10 \mathrm{c}$ & $1 \mathrm{c}$ & $1 \mathrm{c}$ \\
20 & 15 & 100 & $16 \mathrm{~b}$ & $3 \mathrm{~b}$ & $3 \mathrm{~b}$ \\
25 & 10 & 100 & $27 \mathrm{a}$ & $21 \mathrm{a}$ & $21 \mathrm{a}$ \\
30 & 5 & 0 & 0 & 0 & 0
\end{tabular}

Each value represents the mean \pm SE of three replicates per treatment. The data were statistically analyzed using Duncan's Multiple Range Test (DMRT). In the same column, significant differences according to the least significant difference (LSD) at the $P=0.5$ level are indicated by different letters

Table 2 Comparison of the efficiency to generate the putative transgenic plants (mannose and hygromycin resistant) using different genes (PMI and HPTII) in Oncidium

\begin{tabular}{lllll}
\hline $\begin{array}{l}\text { Name of the constructs and } \\
\text { selectable marker genes }\end{array}$ & $\begin{array}{l}\text { No. of PLBs } \\
\text { explants infected }\end{array}$ & $\begin{array}{l}\text { No. of PLB's surviving } \\
\text { on Mannose/hygromycin } \\
\text { medium }\end{array}$ & $\begin{array}{l}\text { No. of regenerated } \\
\text { shoots }\end{array}$ & $\begin{array}{l}\text { No of rooted plantlets } \\
\text { (Mannose/hygromycin resistant) }\end{array}$ \\
\hline pEPYON-42P (35S::PMI) & 100 & $69 \mathrm{a}$ & $31 \mathrm{a}$ & $27 \mathrm{a}$ \\
pEPYON-42H (35S::HPTII) & 100 & $42 \mathrm{~b}$ & $22 \mathrm{~b}$ & $14 \mathrm{~b}$ \\
\hline
\end{tabular}

Each value represents the mean \pm SE of three replicates per treatment. The data were statistically analyzed using Duncan's Multiple Range Test (DMRT). In the same column, significant differences according to the least significant difference (LSD) at the $P=0.5$ level are indicated by different letters 


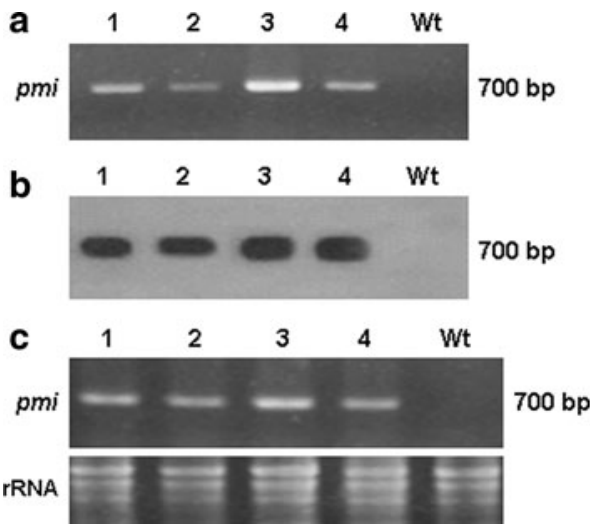

Fig. 4 PCR, Southern hybridization and RT-PCR assay for pEPYON-42P transgenic Oncidium plants. a PCR assay of pmi gene by using primers EcPMI-For and EcPMI-Rev. A 700 bp DNA fragment was amplified. Total genomic DNA was isolated from four $\mathrm{pEPYON-}$ $42 \mathrm{P}$ transgenic $\mathrm{T}_{0}$ Oncidium plants (lane $1-4$ ) and one non transgenic wt plant (lane 5). b Southern blot analysis of transgenic plants. Lanes 1-4 transgenic plants, 5 nontransgenic plant. Genomic DNAs were digested with BamHI and hybridized to a 700 bp pmi-probe. c RTPCR assay of pmi expression by using primers EcPMI-For and EcPMI-Rev. A 700 bp cDNA fragment was amplified. Total RNA was isolated from four $\mathrm{pEPYON}-42 \mathrm{P}$ transgenic $\mathrm{T}_{0}$ Oncidium plants in (a) (lane 1-4) and one non transgenic wt plant (lane 5)

regeneration time in hygromycin and mannose resistant plants of Oncidium (Fig. 5b). Mannose resistant plants were obtained from PLBs within 4 months. In contrast, hygromycin resistant plants required the period of 8 months (Fig. 5b).

\section{Discussion}

The system based on pmi as the selectable marker and mannose as the selective agent was successfully used to recover transgenic Oncidium plants. Genetic transformation using the PMI/mannose system has been carried out in many plant species using mannose (Boscariol et al. 2003; Wang et al. 2000; Todd and Tague 2001; Wright et al. 2001). The addition of sucrose to the selection medium can modulate the inhibitory effect of mannose on shoot formation and can make the recovery of transgenic shoots better in many plants (Joersbo et al. 1998; Negrotto et al. 2000; Zhang and Puonti-Kaerlas 2000; He et al. 2006). In our study, we used $25 \mathrm{~g} \mathrm{l}^{-1}$ mannose and $5 \mathrm{~g}^{-1}$ sucrose. The addition of sucrose and higher concentration of mannose was required for better repression of non transformed shoot formation. He et al. (2004) used 15-20 g l $^{-1}$ mannose in combination with $5 \mathrm{~g}^{-1}$ sucrose to obtain the highest transformation frequency $(6.0 \%)$ for rice plants. In order to eliminate the non-transgenic escapes, the mannose concentration was increased in the course of selection (Table 1; Fig. 2).
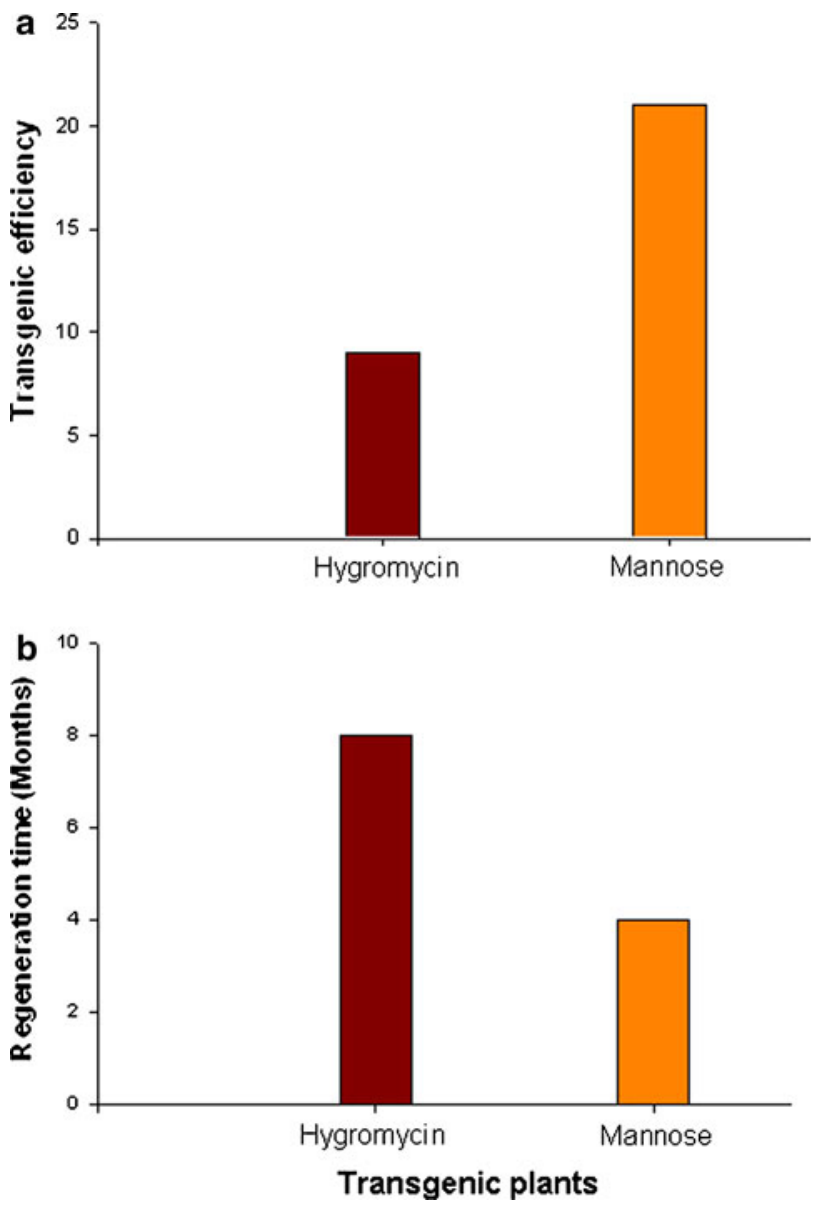

Fig. 5 Transformation efficiency and regeneration of transgenic Oncidium with hygromycin or mannose selection system. a Transgenic efficiency of pEPYON-42H and pEPYON-42P transgenic Oncidium plants. b Culture duration for regeneration of pEPYON$42 \mathrm{H}$ and pEPYON-42P transgenic Oncidium plants

In our transformation study, chopped PLBs pre-treated with 3 days darkness produced more mannose-resistant PLBs. In contrast, 7 days of darkness were needed for Oncidium transformation (Liau et al. 2003). Agrobacterium-mediated transformation, phenolic compounds such as AS serve as a potent inducer for the expression of the virulence (vir) genes located on the $\mathrm{Ti}$ plasmid of A. tumefaciens (Ashby et al. 1987). Since orchids are not natural hosts of A. tumefaciens, previous studies have shown that addition of AS to infection and coculture medium is effective in producing transgenic plants in several orchid species belonging to Dendrobium (Men et al. 2003), Phalaenopsis (Belarmino and Mii 2000) and Oncidium (Liau et al. 2003). Our present results also indicate that the presence of AS during infection and cocultivation period improved the transformation efficiency.

The most common selective protocols for plant transformation are the use of kanamycin, hygromycin, and 
phosphinothricin. We demonstrated that kanamycin was ineffective up to $200 \mathrm{mg} \mathrm{l}^{-1}$ (our unpublished data). Orchids have some level of endogenous resistance to kanamycin (Chai and Yu 2007). The selection of hygromycin inhibits the root formation in transgenic plants of Oncidium (You et al. 2003). Kanamycin and hygromycin are very expensive, it is not recommended because of its high toxicity to humans (Altmann et al. 1992).

The selection strategy based on the use of a PMI gene as selectable gene and mannose as selective agent has proven to be highly efficient. Thus, we obtained transformation frequencies that were significantly higher than hygromycin selection system (Table 2, Fig. 5a). This observation agrees well with the earlier studies in sugar beet (Joersbo et al. 1998), sweet orange (Boscariol et al. 2003), rice (Lucca et al. 2001), maize (Wright et al. 2001) and almond (Ramesh et al. 2006). However, Oncidium orchid is one of the difficult crops to transform using kanamycin selection with a transformation rate of less than 5\% (our unpublished data) and hygromycin system produced transformation efficiency of $9 \%$ (Fig. 5b). You et al. (2003) reported that $12 \%$ of E. carotovora resistant plants ( $p f l p$ ) were obtained. In our present investigation the transformation efficiency was observed higher (21\%), compared to previous Oncidium transformation. In sugar beet, the mannose selection system using Agrobacterium was reported to result in tenfold higher transformation frequencies as compared to kanamycin selection (Joersbo et al. 1998). However, in cassava, the efficiency of hygromycin selection was about twofold higher than that of mannose selection-using PEG mediated particle bombardment (Zhang and PuontiKaerlas 2000). This indicated that transformation frequency on mannose selection varies with each crop. In this study, mannose resistant transgenic plants were obtained less than 4 months (Fig. 5b). In contrast, hygromycin resistant plants were obtained within 8 months (Fig. 5b). This indicated that mannose selected system is not only increased the transformation efficiency but also shorten the duration of regeneration time for Oncidium orchids.

In conclusion, we demonstrated for the first time, that "positive" selection based on mannose is compatible with popular ornamental plants of Oncidium orchid transformation. This mannose system provides an efficient way for transforming the selectable genes of potential commercial value such as genes that regulate flower color, shape, scent and longevity in orchid improvement in the future.

Acknowledgments This work was supported by grants to $\mathrm{C}-\mathrm{H} \mathrm{Y}$ from National Science Council, Taiwan, ROC, grant number: NSC952317-B-005-006 and NSC96-2317-B-005-019. This work was also supported by $5 \mathrm{Y} / 50 \mathrm{~B}$ grant from the Ministry of Education.
Open Access This article is distributed under the terms of the Creative Commons Attribution Noncommercial License which permits any noncommercial use, distribution, and reproduction in any medium, provided the original author(s) and source are credited.

\section{References}

Altmann T, Damm B, Halfter U, Willmitzer L, Morric PC (1992) Protoplast transformation and methods to create specific mutants in Arabidopsis thaliana. In: Koncz C, Chua NH, Schell J (eds) Methods in Arabidopsis research. World Scientific Publishing Co, River Edge, pp 310-330

Ashby AM, Watson MD, Shaw CH (1987) A Ti-plasmid determined function is responsible for chemotaxis of Agrobacterium tumefaciens towards the plant wound product acetosyringone. FEMS Microbiol Lett 41:189-192

Aswath CR, Mo SY, Kim DH, Park SW (2006) Agrobacterium and biolistic transformation of onion using non-antibiotic selection marker phosphomannose isomerase. Plant Cell Rep 25:92-99

Ballester A, Cervera M, Pena L (2008) Evaluation of selection strategies alternative to npt II in genetic transformation of citrus. Plant Cell Rep 27:1005-1015

Belarmino MM, Mii M (2000) Agrobacterium-mediated genetic transformation of a Phalaenopsis orchid. Plant Cell Rep $19: 435-442$

Boscariol RL, Almeida WAB, Derbyshire MTVC, Mourao Filho FAA, Mendes BMJ (2003) The use of the PMI/mannose selection system to recover transgenic sweet orange plants (Citrus sinensis L. Osbeck). Plant Cell Rep 22:122-128

Chai D, Yu H (2007) Recent advances in transgenic orchid production. Orchid Sci Biotechnol 1(2):34-39

Degenhardt J, Poppe A, Montag J, Szankowski I (2006) The use of the phosphomannose-isomerase/mannose selection system to recover transgenic apple plants. Plant Cell Rep 25:1149-1156

Endo S, Kasahara T, Sugita K, Matsunaga E (2001) The isopentenyl transferase gene is effective as a selectable marker gene for plant transformation in tobacco (Nicotiana tabacum cv. Petite Havana SR1). Plant Cell Rep 20:60-66

Fu D, Xiao Y, Muthukrishnan S, Liang GH (2005) In vivo performance of a dual genetic marker, manA-gfp, in transgenic bentgrass. Genome 48:722-730

Goldsworthy A, Street HE (1965) The carbohydrate nutrition of tomato roots VIII. The mechanism of the inhibition by D-mannose of the respiration of excised roots. Ann Bot 29:45-58

Gurel S, Gurel E, Kaur R, Wong J, Meng L, Tan HQ, Lemaux PG (2009) Efficient, reproducible Agrobacterium-mediated transformation of sorghum using heat treatment of immature embryos. Plant Cell Rep 28:429-444

Haldrup A, Petersen SG, Okkels FT (1998) The xylose isomerase gene from Thermoanaerobacterium thermosulfurogenes allows effective selection of transgenic plant cells using D-xylose as the selection agent. Plant Mol Biol 37:287-296

He Z, Fu Y, Si H, Hu G, Zhang S, Yu Y, Sun Z (2004) Phosphomannose-isomerase (pmi) gene as a selectable marker for rice transformation via Agrobacterium. Plant Sci 166:17-22

He Z, Duan Z, Liang W, Chen F, Yao W, Liang H, Yue C, Sun Z, Chen F, Dai J (2006) Mannose selection system used for cucumber transformation. Plant Cell Rep 25:953-958

Höfgen R, Willmitzer L (1988) Storage of competent cells for Agrobacterium transformation. Nucleic Acids Res 16(20):9877

Jain M, Chengalrayan K, Abouzid A, Gallo M (2007) Prospecting the utility of a PMI/mannose selection system for the recovery of 
transgenic sugarcane (Saccharum spp. hybrid) plants. Plant Cell Rep 26:581-590

Joersbo M, Okkels FT (1996) A novel principle for selection of transgenic plant cells: positive selection. Plant Cell Rep 16: 219-221

Joersbo M, Donaldson I, Kreiberg J, Petersen SG, Brunstedt J, Okkels FT (1998) Analysis of mannose selection used for transformation of sugar beet. Mol Breed 4:111-117

Kim JY, Jung M, Kim HS, Lee YH, Choi SH, Lim YP, Min BW, Yang SG, Harn CH (2002) A new selection system for pepper regeneration by mannose. J Plant Biotechnol 4:129-134

Kunze I, Ebneth M, Heim U, Geiger M, Sonnewald U, Herbers K (2001) 2-Deoxyglucose resistance: a novel selection marker for plant transformation. Mol Breed 7:221-227

Lamblin F, Aime A, Hano C, Roussy I, Domon JM, Droogenbroeck BV, Lain'e E (2007) The use of the phosphomannose isomerase gene as alternative selectable marker for Agrobacterium-mediated transformation of flax (Linum usitatissimum). Plant Cell Rep 26:765-772

Lee BT, Matheson NK (1984) Phosphomannoseisomerase and phosphoglucoisomerase in seeds of Cassia coluteoides and some other legumes that synthesize galactomannan. Phytochemistry 23:983-987

Li SH, Kuoh CS, Chen YH, Chen HH, Chen WH (2005) Osmotic sucrose enhancement of single-cell embryogenesis and transformation efficiency in Oncidium. Plant Cell Tissue Organ Cult 81: 183-192

Liau CH, You SJ, Prasad V, Hsiao HH, Lu JC, Yang NS, Chan MT (2003) Agrobacterium tumefaciens-mediated transformation of an Oncidium orchid. Plant Cell Rep 21:993-998

Lucca P, Ye X, Potrykus I (2001) Effective selection and regeneration of transgenic rice plants with mannose as selective agent. Mol Breed 7:43-49

Men S, Ming X, Liu R, Wei C, Li Y (2003) Agrobacterium-mediated genetic transformation of a Dendrobium orchid. Plant Cell Tissue Organ Cult 75:63-71

Miles JS, Guest JR (1984) Nucleotide sequence and transcriptional start point of the phosphomannose isomerase gene (manA) of Escherichia coli. Gene 32:41-48

Min BW, Cho YN, Song MJ, Noh TK, Kim BK, Chae WK, Park YS, Choi YD, Harn CH (2007) Successful genetic transformation of Chinese cabbage using phosphomannose isomerase as a selection marker. Plant Cell Rep 26:337-344

Murashige T, Skoog F (1962) A revised medium for rapid growth and bioassays with tobacco tissue cultures. Physiol Plant 15:473-497

Negrotto D, Jolley M, Beer S, Wenck AR, Hansen G (2000) The use of phosphomannose-isomerase as a selectable marker to recover transgenic maize plants (Zea mays L.) via Agrobacterium transformation. Plant Cell Rep 19:798-803

O'Kennedy MM, Burger JT, Botha FC (2004) Pearl millet transformation system using the positive selectable marker gene phosphomannose isomerase. Plant Cell Rep 22:684-690

Patil G, Deokar A, Jain PK, Thengane RJ, Srinivasan R (2009) Development of a phosphomannose isomerase-based Agrobacterium-mediated transformation system for chickpea (Cicer arietinum L.). Plant Cell Rep 28:1669-1676
Privalle LS, Wright M, Reed J, Hansen G, Dawson J, Dunder EM, Chang YF, Powell ML, Meghji M (1999) Phosphomannose isomerase, a novel selectable plant selection system: mode of action and safety assessment. In: Fairbain G, Scoles A (eds) International symposium on biosafety of genetically modified organisms. Saskatoon, Canada, pp 171-178

Ramesh SA, Kaiser BN, Franks T, Collins G, Sedgley M (2006) Improved methods in Agrobacterium-mediated transformation of almond using positive (mannose/pmi) or negative (kanamycin resistance) selection-based protocols. Plant Cell Rep 25:821-828

Reed J, Privalle L, Powell ML, Meghji M, Dawson J, Dunder E, Suttie J, Wenck A, Launis K, Kramer C, Chang YF, Hansen G, Wright M (2001) Phosphomannose isomerase: an efficient selectable marker for plant transformation. In Vitro Cell Dev Biol Plant 37:127-132

Sambrook J, Fritsch EF, Maniatis T (1989) Molecular cloning: a laboratory manual, 2nd edn. Cold Spring Harbor Laboratory Press, Cold Spring Harbor

Sigareva M, Spivey R, Willits MG, Kramer CM, Chang YF (2004) An efficient mannose selection protocol for tomato that has no adverse effect on the ploidy level of transgenic plants. Plant Cell Rep 23:236-245

Thiruvengadam M, Yang CH (2010) Overexpression of Oncidium MADS box (OMADS1) gene promotes early flowering in transgenic orchid (Oncidium Gower Ramsey). Plant Cell Rep (under review)

Todd R, Tague BW (2001) Phosphomannose isomerase: a versatile marker for Arabidopsis thaliana germ-line selectable transformation. Plant Mol Biol Rep 19:307-319

Wang AS, Evans RA, Altendorf PR, Hanten JA, Doyle MC, Rosichan JL (2000) A mannose selection system for production of fertile transgenic maize plants from protoplasts. Plant Cell Rep 19: $654-660$

Wright M, Dawson J, Dunder E, Suttie J, Reed J, Kramer C, Chang Y, Novitzky R, Wang H, Artim-Moore L (2001) Efficient biolistic transformation of maize (Zea mays L.) and wheat (Triticum aestivum $\mathrm{L}$.) using the phosphomannose isomerase gene, pmi as the selectable marker. Plant Cell Rep 20:429-436

You SJ, Liau CH, Huang HE, Feng TY, Prasad V, Hsiao HH, Lu JC, Chan MT (2003) Sweet pepper ferredoxin-like protein ( $p f p$ ) gene as a novel selection marker for orchid transformation. Planta 217:60-65

Zhang P, Puonti-Kaerlas J (2000) PIG-mediated cassava transformation using positive and negative selection. Plant Cell Rep 19: 1041-1048

Zhu YJ, Agbayani R, McCafferty H, Albert HH, Moore PH (2005) Effective selection of transgenic papaya plants with the PMI/ Man selection system. Plant Cell Rep 24:426-432

Zuo J, Niu QW, Ikeda Y, Chua NH (2002) Marker free transformation increasing transformation frequency by the use of regeneration promoting gene. Curr Opin Biotechnol 13:173-180 